\title{
Short-term retreat statistics of a slowly eroding coastal cliff
}

\author{
A. P. Young ${ }^{1}$, R. T. Guza ${ }^{1}$, W. C. O'Reilly ${ }^{1}$, R. E. Flick ${ }^{1}$, and R. Gutierrez ${ }^{2}$ \\ ${ }^{1}$ Integrative Oceanography Division, Scripps Institution of Oceanography, University of California San Diego, La Jolla, \\ California, USA \\ ${ }^{2}$ Center for Space Research, The University of Texas at Austin, Austin, Texas, USA
}

Received: 29 July 2010 - Revised: 28 October 2010 - Accepted: 4 December 2010 - Published: 21 January 2011

\begin{abstract}
The frequency, spatial distribution, and dimensions of coastal cliff retreats, a basic statistic underlying cliff top hazard assessment, are presented for $7.1 \mathrm{~km}$ of unprotected and slowly retreating coastal cliffs near Point Loma in San Diego, California, US. Using 8 airborne light detection and ranging (lidar) surveys collected over 5.5 years, 130 individual cliff edge failures (primarily rockfalls, block falls, and topples) were detected. Footprint areas varied from 3 to $268 \mathrm{~m}^{2}$, maximum landward retreats from 0.8 to $10 \mathrm{~m}$, and alongshore lengths from 2 to $68 \mathrm{~m}$. The failures with the largest landward retreats were also relatively long, and $13 \%$ of the slides accounted for $50 \%$ of the lost cliff area over the study period. On this short (5.5 years) time scale, "no change" was the most common observation ( $84 \%$ of the cliff edge). Probability distributions of non-zero cliff retreat during each time interval usually had a single peak between 1 and $2.5 \mathrm{~m}$. Intervals with high mean retreat had elevated numbers of failure in all class sizes, and also contained the largest individual retreats. Small and medium slides tended to reoccur preferentially (relative to randomly) near previous small and medium slides, forming short-term hot spots, while large slides were less likely to reoccur near previous large slides. Cumulative distributions of landslide failure parameters (area, mean retreat, maximum retreat, and length) follow an inverse power-law for medium to large size events, similar to previously reported distributions of coastal and inland landsliding.
\end{abstract}

\section{Introduction}

Seacliff retreat threatens cliff top infrastructure, and estimates of future cliff positions are needed for coastal planning. Multiple marine and subaerial erosive processes

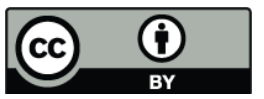

Correspondence to: A. P. Young (adyoung@ucsd.edu) interact with complex site-specific local geology to produce temporally and spatially variable retreat (Trenhaile, 1987; Sunamura, 1992). The limited available historical observations provide mean (time-and-alongshore averaged) retreat rates, but extrapolation of these rates to estimate sitespecific future risk is problematic because the magnitude variability (in space and time) of cliff retreat is not considered (Cambers, 1976; Lee et al., 2001; Moore and Griggs, 2002; Quinn et al., 2009). Retreat magnitude variability and episodicity are included in recent probabilistic characterizations of cliff retreat (e.g. Lee et al., 2001, 2002; Hall et al., 2002; Williams et al., 2004; Teixeira, 2006; Milheiro-Oliveira, 2007; Furlan, 2008). These models highlight both the need for, and the scarcity of, observations of even basic statistics such as the dependence of cliff retreat frequency on retreat magnitude.

The statistics of inland mass movements have been studied extensively (e.g. Hovius et al., 1997; Pelletier et al., 1997; Dai and Lee, 2001; Dussauge-Peisser et al., 2002; Guzzetti et al., 2002; Hergarten, 2003; Brardinoni and Church, 2004; Brunetti et al., 2009; ten Brink et al., 2009). Historical records of coastal cliff failure statistics are relatively sparse. Dong and Guzzetti (2005) investigated the frequency statistics of soft cliff retreat for two data sets. The first (obtained from Hall et al., 2002) consisted of 32 (26 non-zero) measurements made along eight transects over four time intervals ranging from 7 to 29 years at East End in East Sussex, England. The second data set included 198 (168 non-zero) yearly measurements from 1953 to 1990 along six transects on the Holderness coast, England. For both datasets, the frequency of cliff retreat decreases with event size, and medium to large size events follow an inverse power-law distribution.

Teixeira (2006) investigated the frequency statistics and geometric relationships of coastal mass movements in Miocene aged rock cliffs of the Algarve, Portugal. These datasets consisted of 140 field measurements obtained over

Published by Copernicus Publications on behalf of the European Geosciences Union. 
nine years, and 177 events obtained from aerial photographs over 44 years. The cumulative frequency of cliff retreat for both datasets fit a power-law distribution above a critical value, and deviated for relatively small events. Teixeira (2006) also found power-law relationships between volume, horizontal area, and retreat. Marques (2008) further investigated the magnitude-frequency statistics of strong, slowly retreating coastal cliffs $\left(<10 \mathrm{~cm} \mathrm{yr}^{-1}\right)$ in terms of volume, horizontal area, and cliff retreat. The database included about 600 events from regional scale observations obtained from aerial photographs spanning up to 53 years in Portugal and Morocco, and smaller scale insitu field observations (from Teixeira, 2006) in Portugal.

Rosser et al. (2007) used high resolution monthly terrestrial laser scans collected over 32 months in the North York Moors National Park, UK to compile a large database of over 500000 coastal rockfalls. Rockfall volume and scar area (parallel to the rock face) followed a power law, and the cumulative distribution followed a linear trend for log volume versus normalized frequency. Their results suggested that rock type influenced scar geometry, and that smaller rockfalls often preceded larger failures.

Lim et al. (2010) recently compiled a database over 100000 coastal rockfalls using monthly terrestrial laser scanning and orthophotography over 20 months at Staithes, North Yorkshire, UK. They found a linear trend in the non-cumulative distribution of $\log$ volumes, including the small changes that were resolved with their uniquely highresolution observations. These results suggest undersampling of small cliff failures caused the deviation of the magnitude-frequency relationships found previously in coastal (Dong and Guzzetti, 2005; Teixeira, 2006; Marques, 2008) and inland (e.g. Hovius et al., 1997; Stark and Hovius 2001; Dussauge-Peisser et al., 2002; Malamud et al., 2004) observations.

The different methods, measured parameters, and failure types make comparisons of failures from different studies difficult. For example Teixeira (2006) and Marques (2008) report horizontal (planimetric) area while Rosser et al. (2007) and Lim et al. (2010) consider area parallel to the cliff face. Some studies focus on magnitude-frequency relationships of cliff retreat (Dong and Guzzetti, 2005; Teixeira, 2006) while others on failure volume (Rosser et al., 2007; Lim et al., 2010). Cliff edge retreat failures, a subset of the cliff failures, are generally used in models to establish structural setbacks, while volumetric statistics are more appropriate for processed-based modeling. Many authors note that additional cliff failure inventories are required to assess the generality and predictive utility of observationbased, statistical characterizations of cliff retreat. The present study uses 8 airborne lidar surveys collected over 5.5 years to describe basic two dimensional (planimetric), short-term (5.5 yr) statistics of cliff edge failures over $7.1 \mathrm{~km}$ of unprotected coastal rock cliffs in southern California, US.

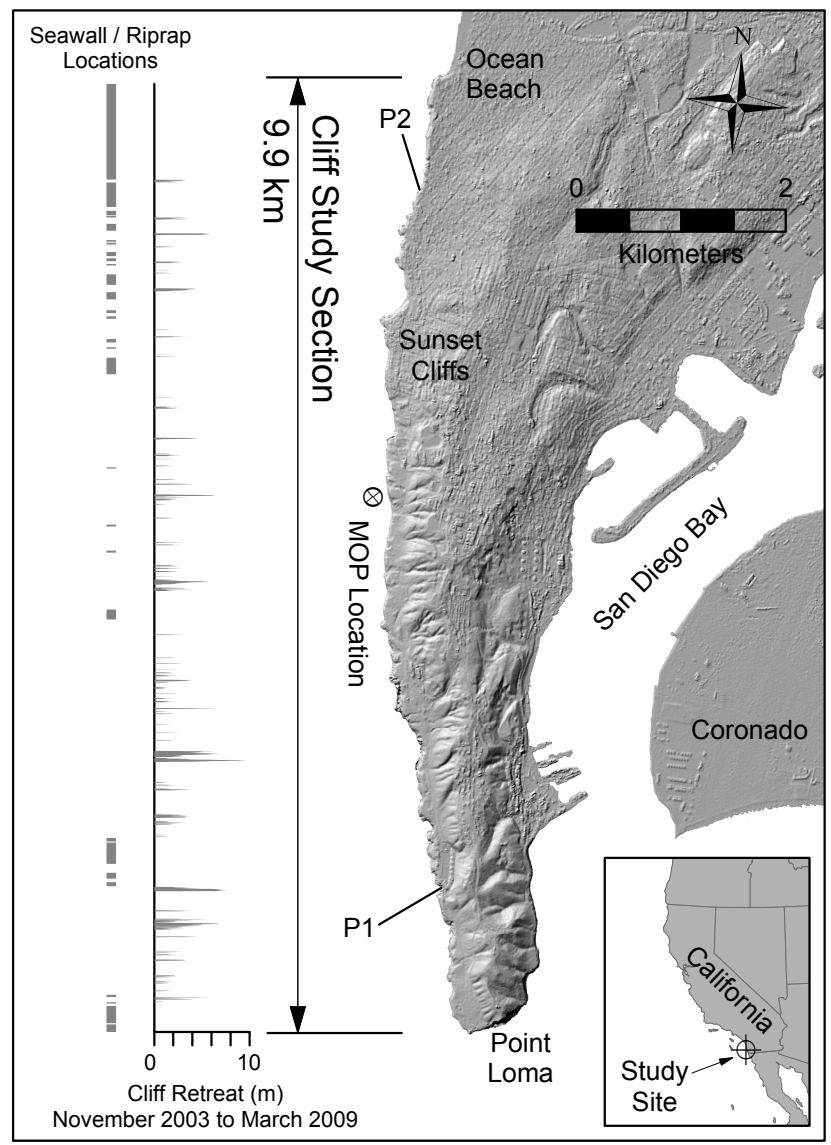

Fig. 1. Location map of the Sunset Cliffs to Point Loma study area showing alongshore projected locations of seawall/riprap and the cumulative cliff retreat (unprotected cliffs) occurring during the study period (October 2003 to March 2009). At least two locations (P1 and P2) with seawall/riprap experienced significant erosion.

\section{Study area}

\subsection{General description}

The southern California study area extends from the southwest end of Point Loma to Ocean Beach in southern San Diego County, California (Fig. 1) consisting of $9.9 \mathrm{~km}$ of shoreline. The cliff top in the northern section is developed with the residential communities of Sunset Cliffs and Ocean Beach, while the southern section contains important infrastructure including a wastewater treatment plant, the Point Loma lighthouse, and US Navy facilities. Cliff retreat has undermined Sunset Cliffs Blvd. (Shepard and Grant IV, 1947), and resulted in building condemnation (Flick, 2005). Riprap and seawalls protect about $28 \%$ $(2.8 \mathrm{~km})$ of the cliffs, mostly in the northern section (Fig. 1). Tides are mixed with a maximum range of about $2 \mathrm{~m}$. 


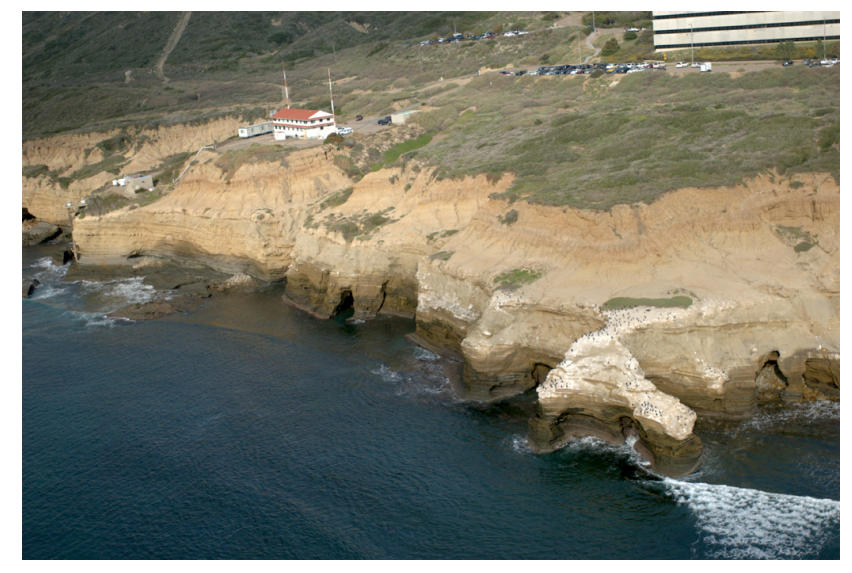

Fig. 2. Oblique photo showing the general stratigraphy and landscape of the study area (photo by Darren Wright, California Data Information Program).

\subsection{Geology}

Point Loma is a rock promontory uplifted by the Rose Canyon section of the Rose Canyon-Newport-Inglewood Fault. The seacliffs exposed on the seaward side of the promontory are generally 20 to $30 \mathrm{~m}$ high (range of 5 to $40 \mathrm{~m}$ ), and are composed of two geologic units (Fig. 2). The lower unit is the Point Loma Formation, a lithified Cretaceous interbedded fine grain sandstone and shale, unconformably overlain by the Bay Point Formation, a poorly consolidated Pleistocene sandstone terrace deposit (Kennedy, 1975). The contact between the two units decreases in elevation towards the north, where it intersects the cliff base in the heavily armored section of Ocean Beach. The Point Loma Formation often forms a vertical cliff face except where undercut, while the weaker Bay Point Formation tends to form slope angles of about $30^{\circ}$ (Figs. 2 and 3). There are two common cliff profiles; (1) nearly entirely vertical and composed primarily of the Point Loma Formation, and (2) a sloped upper cliff composed of the Bay Point Formation (Fig. 3). According to Emery and Kuhn (1982), both profiles indicate that marine erosion dominates subaerial erosion. However, Kuhn and Shepard (1984) and Flick (1994) document accelerated local erosion caused by concentrated surface runoff, and the relative importance of marine versus subaerial processes is unknown. Although the statistical failure properties described are for unprotected cliffs, they may be affected by adjacent armored cliffs and cliff top development.

Joints, fractures, and a series of northeasterly intersecting faults create weak areas in the lower cliff, resulting in alongshore variable cliff resistance, and a highly irregular shoreline containing sea caves, wave cut notches, surge channels, small headlands, a few pocket beaches, and an occasional sea stack, arch, or blow-hole. The shore platform,
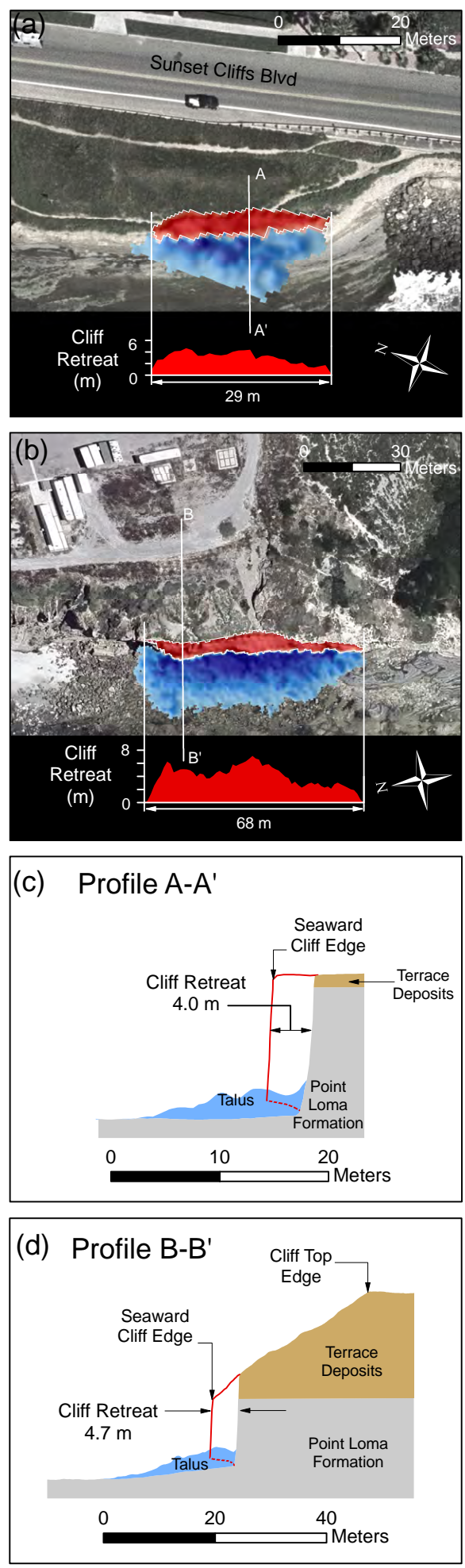

Fig. 3. Areas of large cliff failures (red) and resulting talus deposition (blue) that occurred in (a) Interval 5, and (b) Interval 2. Lower inset: cliff retreat versus alongshore location. (c) Schematic cut-away view on profiles A-A' and (d) B-B' before (red line) and after the cliff failures. Typical notch profiles in (c) and (d) were estimated from oblique photos (www.californiacoastline.org). Scale bars in panels (c) and (d) represent both the cross-shore and vertical cliff dimensions. 
composed of the Point Loma Formation, is often submerged at the cliff base and lacking beach sand (with the exception of a few narrow pocket beaches), with wave attack during average or higher tide stages. At some locations, the shore platform elevation allows wave attack at all tide stages. Cliff undercutting at the cliff base from wave action is often present and can result in cliff instability, as at other cliffs (Hampton, 2002; Kogure et al., 2006; Young and Ashford, 2008; Budetta, 2010). Cliff failures in the Point Loma Formation generally occur as rock falls, block falls, and topples (Varnes, 1978).

\subsection{Historical erosion}

Historical photographs of Sunset Cliffs-Point Loma (Shepard and Grant IV, 1947; Shepard and Wanless, 1971; Kuhn and Shepard, 1984) show the collapse of sea arches and sea caves, the erosion of sea stacks, and an earthquaketriggered cliff failure. Kennedy (1973) used old photographs and observations to estimate an average cliff retreat rate of $1.2 \mathrm{~cm} \mathrm{yr}^{-1}$ over 75 years, and noted that some sea caves extend landward as much as $18 \mathrm{~m}$ from the cliff face. Average cliff retreat of $8 \mathrm{~cm} \mathrm{yr}^{-1}$ between 1952 and 1994 was estimated using orthorectified aerial photographs (Benumof and Griggs, 1999; Moore et al., 1999; Benumof et al., 2000). Spaulding and Crampton (2001) estimated retreat rates of 2 to $6 \mathrm{~cm} \mathrm{yr}^{-1}$ for a small portion of Sunset Cliffs over a 70-year period beginning in 1928 from aerial photographs. Hapke and Reid (2007a) used 1934 T-sheets and a 1998 lidar survey to estimate cliff retreat rates along cross-shore transects that average to $17 \mathrm{~cm} \mathrm{yr}^{-1}$. Several studies (Shepard and Grant IV, 1947; Kennedy, 1973; Spaulding and Crampton, 2001) indicated no observable erosion at some locations over considerable time periods, while others (Kuhn and Shepard, 1984; Hapke and Reid, 2007b) found local cliff retreat rates as large as $100 \mathrm{~cm} \mathrm{yr}^{-1}$. The large range of average long-term cliff retreat estimates results from differences in data quality, time period evaluated, cliff armoring, and study section. There is general agreement that cliff retreat is episodic in both space and time. Shepard and Wanless (1971) state "the coast is retreating, although very unevenly", while Kennedy (1973) noted cliff retreat is "regionally negligible and locally high".

\subsection{Climate}

San Diego's semi-arid Mediterranean climate is characterized by dry summers and occasionally wet winters, with $85 \%$ of rainfall from November through March. Annual precipitation amounts vary from about 10 to $60 \mathrm{~cm}$, and average $25 \mathrm{~cm}$. Rainfall during the study period was average or less, except for winter 2004 to 2005 (Interval 2), when rainfall exceeded twice the annual average (Fig. 4).

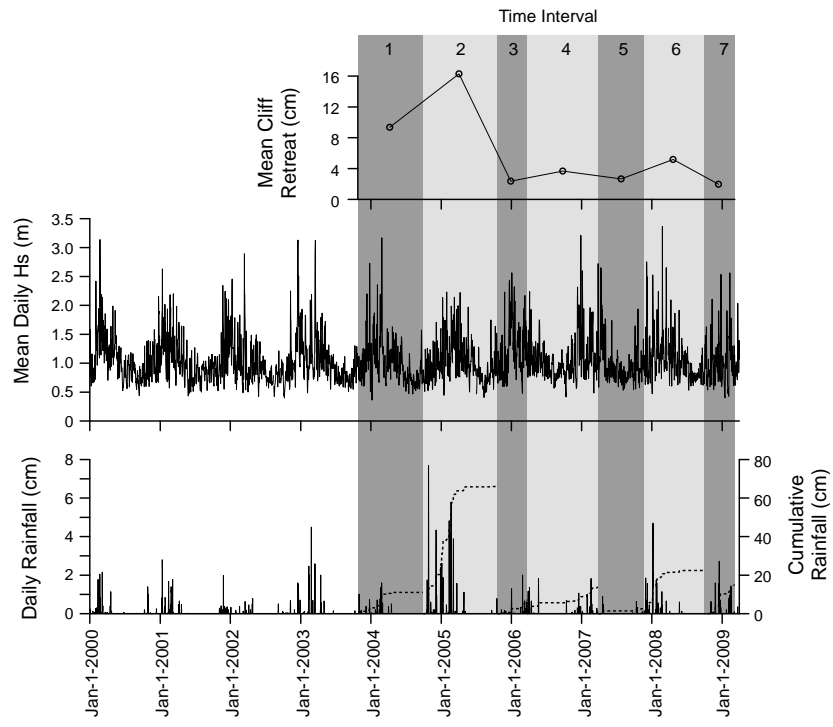

Fig. 4. Top: mean section cliff retreat occurring during each time interval. Center: mean daily significant wave height $\left(H_{\mathrm{S}}\right)$ at a virtual buoy located seaward of the cliff section in $10 \mathrm{~m}$ water depth (monitoring and prediction point location (MOP), Fig. 1). Bottom: daily rainfall totals and cumulative daily rainfall during each interval (dotted line) at Cabrillo National Monument (http://www.wrh.noaa.gov/sgx/obs/rtp/cabrillo.html) located at the southern end of the study area. Gray bars indicate time periods between lidar surveys used in this study.

\subsection{Waves}

The seacliffs are exposed to swell from distant storms in both hemispheres and waves generated by local winds. During winter, swell from the North Pacific and the Gulf of Alaska are most energetic, whereas swell from the South Pacific dominates in summer. The seasonal cycle produces maximum wave energy in winter (Fig. 4). Wave conditions vary alongshore, and were estimated from a wave buoy network (CDIP, http://cdip.ucsd.edu) and a spectral refraction wave model that accounts for the effects of complex bathymetry in the southern California Bight, varying beach orientation, and wave exposure (O'Reilly and Guza, 1991, 1998). Mean daily significant wave height $\left(H_{\mathrm{S}}\right)$ at a virtual buoy or "Monitoring and Prediction point" (MOP) located in $10 \mathrm{~m}$ water depth seaward of the cliff section (Fig. 1), shows that wave heights were typical during the study period (Fig. 4). Although wave conditions vary alongshore, the patterns of seasonal and interannual variation are similar at all the study cliffs. Complex small scale cliff-base geometry precludes detailed estimates of location-specific marine erosional forces. 


\subsection{Seismicity}

Minor ground motions are relatively common in the tectonically active San Diego region. However, no earthquakes with magnitude $>5.0$ occurred within $100 \mathrm{~km}$ of the study site, during the study period (www.data.scec.org).

\section{Methods}

\subsection{Lidar data collection}

Eight airborne lidar surveys (Table 1) were conducted between October 2003 and March 2009 with an Optech Inc. Airborne Laser Terrain Mapper (ALTM) 1225. Each airborne survey consisted of 2 to 4 passes with a $40^{\circ}$ swath at an altitude ranging from 300 to $1150 \mathrm{~m}$ resulting in a point density of approximately 2 to 4 points $\mathrm{m}^{-2}$. The alongshore aircraft trajectory was located approximately 0 to $100 \mathrm{~m}$ seaward of the seacliffs. ALTM elevation points are computed using three sets of data: laser ranges and their associated scan angles, platform position and orientation information, and calibration data and mounting parameters (Wehr and Lohr, 1999). GPS receivers in the aircraft and on the ground at control points provide platform positioning. The GPS receivers record pseudorange and phase information for post-processing. Platform orientation information comes from an Inertial Measurement Unit (IMU) containing three orthogonal accelerometers and gyroscopes. An aided-Inertial Navigation System (INS) solution for the aircraft's attitude is estimated from the IMU output and the GPS information.

\subsection{Digital elevation model}

Lidar data was occasionally obtained in over-hanging locations such as seacaves and notches, however the partial coverage did not permit construction of fully 3-D terrain models, and volume statistics could not be estimated. Therefore, the point data were processed into $0.5 \mathrm{~m}$ resolution 2.5-D digital elevation models using the second of two returns (the most representative of the ground surface) and a modified "natural neighbors" interpolation that removes over-vertical features and maintains vertical cliff edges and complex topography (see Appendix A, LEMDEM).

\subsection{Change detection and cliff retreat}

Vertical topographic change for the seven time intervals (Table 1), obtained by differencing successive digital elevations models to create digital change grids (DCG), shows erosion (negative changes) at failure locations, and accretion (positive changes) at cliff base talus deposits (Fig. 3). Sources of errors in the DCGs include the basic lidar observations, spatial interpolation, and vegetation. The vertical root mean square difference between two surveys $\left(\mathrm{RMS}_{\mathrm{Z}}\right.$, Federal Geographic Data Committee, 1998), a measure of the total error, was estimated using three control sections of stabilized slopes and seawalls that represent the range of slopes and vegetative conditions of the studied seacliffs. The average $\mathrm{RMS}_{\mathrm{Z}}$ of all control sections and intervals was $18 \mathrm{~cm}$, and ranged from 10 to $24 \mathrm{~cm}$.

The DCGs were filtered and edited to remove noise and identify the individual failures causing seaward cliff edge retreat. First, all grid cells with a vertical change of less than $2 \mathrm{~m}\left(\gg \mathrm{RMS}_{\mathrm{Z}}\right)$ were removed. Next, a minimum topographic footprint was imposed, requiring at least 12 connected cells of negative change, thus enforcing a minimum change area of $3 \mathrm{~m}^{2}$. The vertical and footprint thresholds, selected through trial and error and tested on the control surfaces, significantly reduced noise. Finally, the digital data footprints were visually inspected, yielding the topographic footprints of individual seaward cliff-edge failures during each time interval. The seaward cliff edge was used as the shoreline reference feature because cliff retreat is readily identifiable for landslides occurring in both profile types (Fig. 3). The seaward edge was coincident with the cliff top edge when the upper cliff slope was vertical (Fig. 3c). These interval changes could represent combined individual, adjacent landslides that occurred during a particular time interval.

\subsection{Cliff failure parameters}

Cliff failure footprints were sampled on local cross-shore oriented transects spaced $1.0 \mathrm{~m}$ alongshore (Fig. 5). The DCGs usually were not aligned with the local shoreline orientation, resulting in a range of retreat measurements (including values less than the grid size) rather than increments of the $0.5 \mathrm{~m}$ grid size. The alongshore failure length was defined as the number of transects intersecting the failure footprint. Mean failure retreat was estimated as the average of intersecting transects for each slide, while the maximum failure retreat represents the longest intersecting transect. The cliff footprint area was measured as the planimetric area on the DCGs. Note this method can result in small differences between the measured planimetric area, and area calculated as the product of alongshore failure length and mean failure retreat, but provides a simple automated way to estimate cliff failure attributes with locally changing shoreline orientation.

\section{Results and discussion}

\subsection{Erosion at protected cliffs}

Retreat at cliffs with riprap or seawalls was relatively minor, however at least two protected locations (P1 and P2, Fig. 1) experienced significant erosion. At P1 during Interval 2, a mid-cliff failure in the Point Loma Formation occurred 


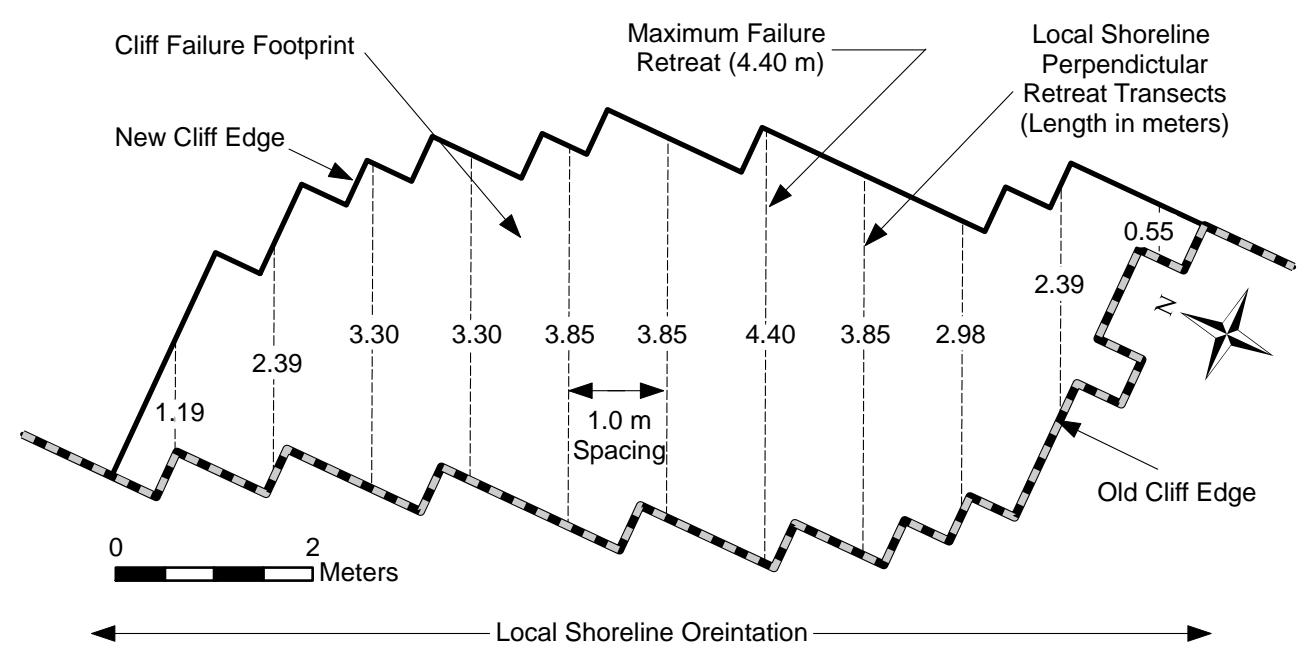

Alongshore Failue Length $=11.0 \mathrm{~m} \quad$ (11 intersecting transects)

Mean Failure Retreat $=2.92 \mathrm{~m}$ (average of intersecting transects)

Maximum Failure Retreat $=4.40 \mathrm{~m}$ (longest intersecting transect)

Failure Area $=32.25 \mathrm{~m}^{2} \quad$ (planimetric failure footprint area)

Fig. 5. Example of a cliff failure footprint, local shoreline perpendicular retreat transects, and estimated failure attributes and geometry. Intersecting transects cross the failure footprint, determined on a $0.5 \mathrm{~m}$ grid. The old cliff edge (thick dashed gray/black line) and new cliff edge (thick solid black line) bound the cliff failure footprint.

between a rock revetment at the cliff base and an upper cliff retaining wall. Erosion (primarily of the terrace deposits) at location P2 occurred during Intervals 1 through 4 and 7, and involved a seawall failure with loss of residential property. These events (and others at protected cliffs) are excluded from further consideration because cliff protection significantly alters cliff failures.

\subsection{Cliff failure footprint, geometry, correlations, and probabilities}

The 130 individual cliff edge failure footprints ranged in area from 3 to $268 \mathrm{~m}^{2}$ with a mean of $22 \mathrm{~m}^{2}$ (Appendix A, Table A1). Alongshore failure lengths ranged from 2 to $68 \mathrm{~m}$ with a mean of $10 \mathrm{~m}$. The mean and maximum failure retreat measured perpendicular to the local shoreline orientation ranged from 0.7 to $5.8 \mathrm{~m}$, and from 0.8 to $10.0 \mathrm{~m}$, respectively. Although the alongshore failure length and mean retreat distance are correlated (mean retreat $\sim 0.14$ length, Fig. 6 ), there is considerable variation in the length/retreat ratio, with the largest variation for large slides. For example, the largest mean retreats (between 3 and $6 \mathrm{~m}$ ) have alongshore lengths varying by a factor of 17 (between 4 and $68 \mathrm{~m}$ ). The shortest of slides with relatively large mean retreat (between 3 and $6 \mathrm{~m}$ ) usually occurred in areas with relatively complex alongshore shape, whereas the longest slide was relatively straight alongshore. Geologic discontinuities (e.g. joints and faults) can exert strong control on cliff failure dimensions (Kogure and Matsukura, 2010), and likely affected the observed failure geometries.

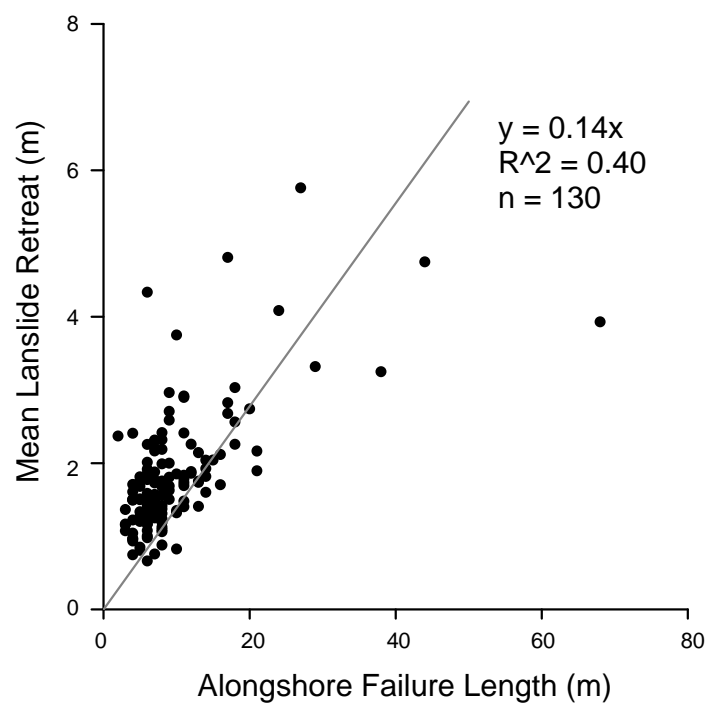

Fig. 6. Mean failure retreat versus alongshore failure length for the 130 slides.

The larger area, infrequent failures contributed substantially to the mean (cliff-wide) retreat over the entire study period. For example, the 17 (13\% of the total number of failures) largest failures comprised $50 \%$ of the total lost cliff area. The single largest failure extended $68 \mathrm{~m}$ alongshore (Interval 2, Fig. 3b), equivalent to $3.7 \mathrm{~cm}$ of retreat averaged over the entire study section. This single failure was equivalent or more than the mean retreat in Intervals 3, 4, 5 or 7 (Table 1). 
Table 1. Interval information.

\begin{tabular}{|c|c|c|c|c|c|c|c|c|}
\hline Interval & 1 & 2 & 3 & 4 & 5 & 6 & 7 & $1-7$ \\
\hline Start Date & 25 Oct 2003 & 29 Sep 2004 & 19 Oct 2005 & $24 \operatorname{Mar} 2006$ & $28 \operatorname{Mar} 2007$ & 23 Nov 2007 & 28 Sep 2008 & 25 Oct 2003 \\
\hline End Date & 29 Sep 2004 & 19 Oct 2005 & 24 Mar 2006 & $28 \operatorname{Mar} 2007$ & 23 Nov 2007 & 28 Sep 2008 & 8 Mar 2009 & 8 Mar 2009 \\
\hline Time Length (Days) & 340 & 385 & 156 & 369 & 240 & 310 & 161 & 1961 \\
\hline Time Length (Years) & 0.9 & 1.1 & 0.4 & 1.0 & 0.7 & 0.8 & 0.4 & 5.4 \\
\hline Mean Retreat (cm) & 9.4 & 16.3 & 2.4 & 3.7 & 2.7 & 5.2 & 2.0 & 41.7 \\
\hline Mean Retreat Rate $\left(\mathrm{cm} \mathrm{yr}^{-1}\right)$ & 10.0 & 15.4 & 5.7 & 3.6 & 4.1 & 6.1 & 4.5 & 7.8 \\
\hline Maximum Retreat (m) & 10.0 & 7.1 & 5.8 & 5.9 & 4.8 & 6.0 & 3.7 & 10.0 \\
\hline Extent of Cliff Retreat (m) & 248 & 473 & 98 & 155 & 78 & 155 & 81 & $1288 / 1153^{*}$ \\
\hline Area Lost $\left(\mathrm{m}^{2}\right)$ & 655 & 1146 & 166 & 254 & 186 & 367 & 137 & 2910 \\
\hline Number of Landslides & 24 & 42 & 13 & 21 & 8 & 14 & 8 & $130 / 102^{* *}$ \\
\hline
\end{tabular}

* 1288 (sum of interval extent)/1153 (extent considering amalgamation over the combined intervals).

** 130 (sum of interval slides)/102 (slides considering amalgamation over the combined intervals).
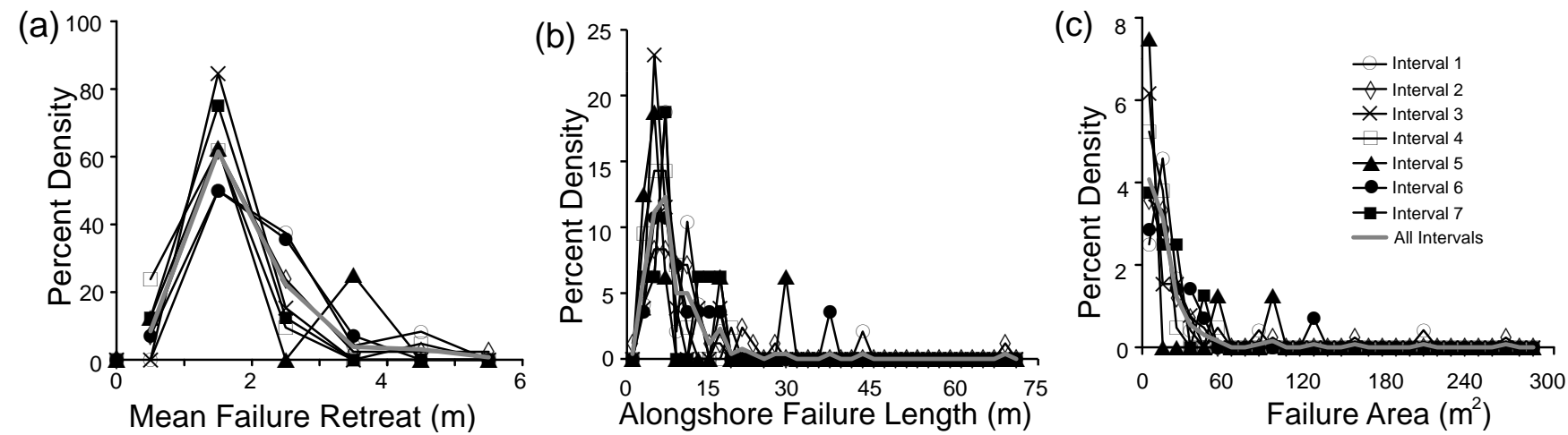

Fig. 7. Probability density of individual failures (a) mean retreat $\left(\% \mathrm{~m}^{-1}\right)$, (b) alongshore length, $\left(\% \mathrm{~m}^{-1}\right)$ and (c) area $\left(\% \mathrm{~m}^{-2}\right)$ during each time interval, and averaged over all intervals (see legend).
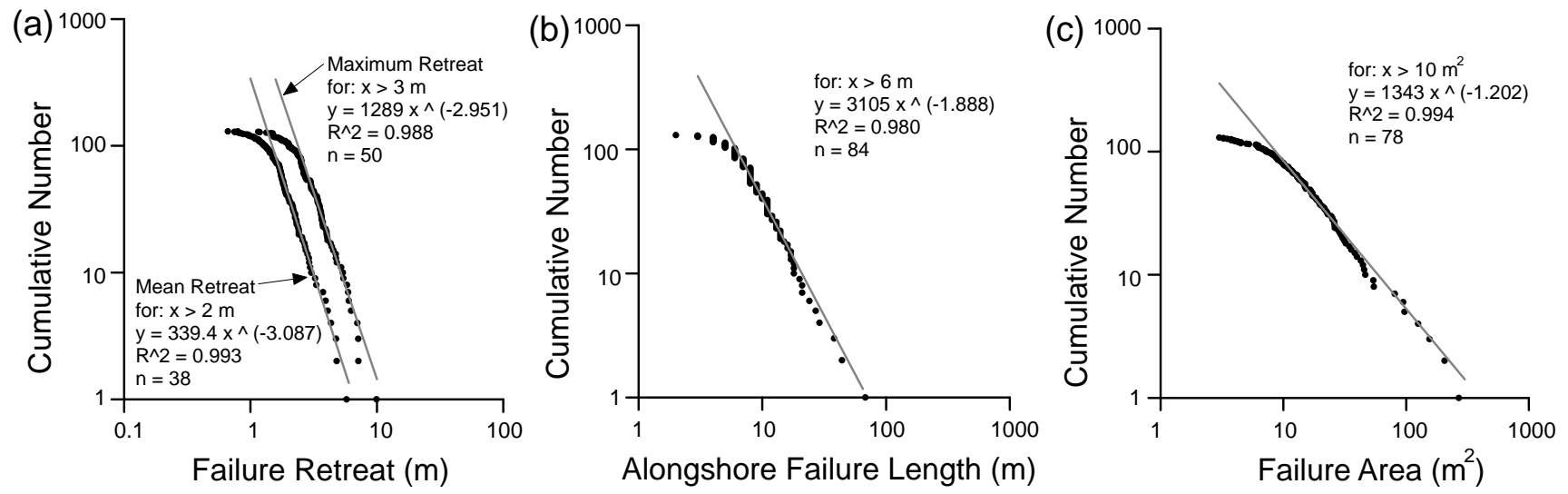

Fig. 8. Log of the cumulative number of failures versus log of (a) mean and maximum failure retreat, (b) alongshore length, and (c) area.

Probability density functions characterizing the calculated mean failure retreat (Fig. 7a), alongshore distance (Fig. 7b), and area (Fig. 7c) of individual slides are generally similar between intervals and are right skewed. The cumulative distributions of individual failure parameters; mean and maximum retreat (Fig. 8a), alongshore distance (Fig. 8b), and area (Fig. 8c), all fit well to inverse power-law distributions for relatively medium-large size events. The scaling exponent of the cliff-edge failure area cumulative distribution ( $b=1.2$, Fig. $8 \mathrm{c}$ ), is similar to the $b \sim 1.0$ found by Marques (2008). Unimodal cliff failure probability density functions (Fig. 7), and power-law cumulative distributions for medium-large events were also reported by Dong and Guzzetti (2005) and Marques (2008). Small events were not reliably detected in these studies, and areas $<3 \mathrm{~m}^{2}$ are excluded from the present statistics. 

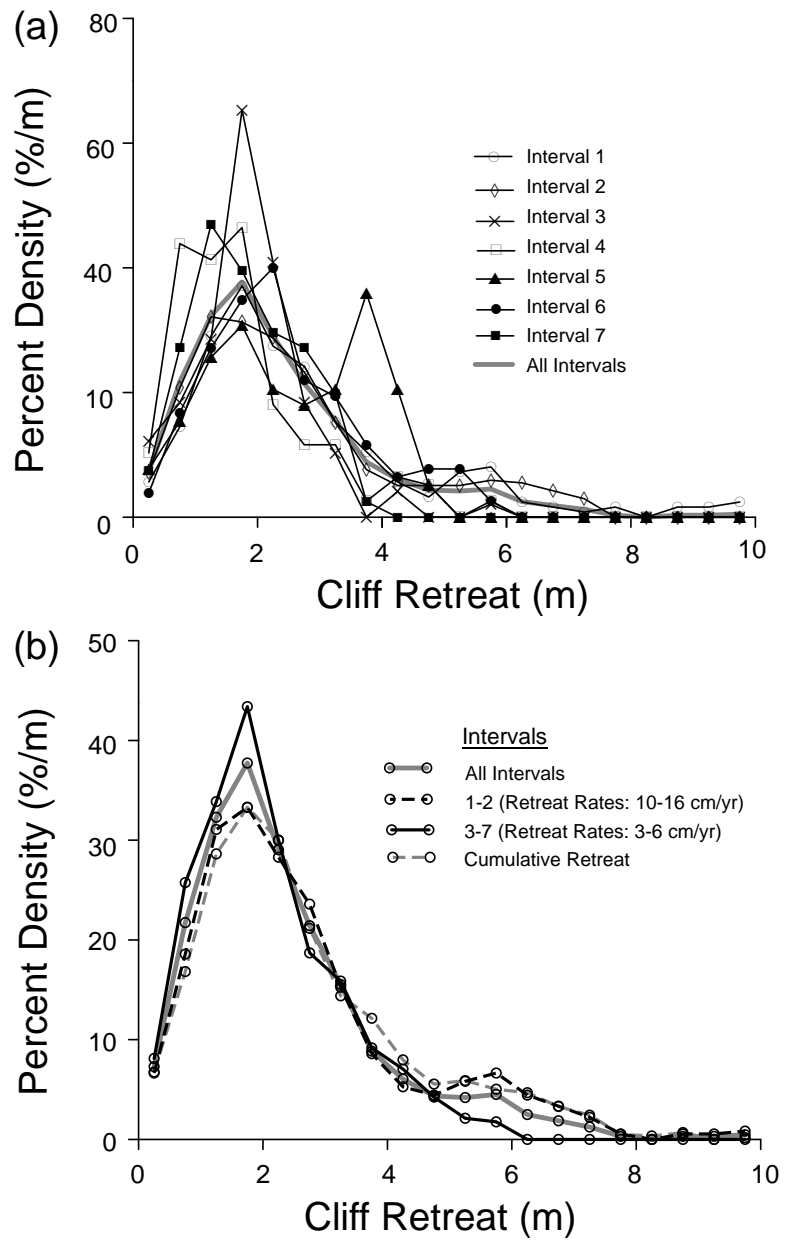

Fig. 9. Probability density functions of transect (a) cliff retreat occurring during each time interval, and (b) combined time periods with relatively high (Intervals 1 and 2) and low retreat rates (Intervals 3 through 7). The probability density functions are based on $0.5 \mathrm{~m}$ intervals and plotted along the $\mathrm{x}$-axis using the midinterval location.

\subsection{Footprint transect retreat measurements}

The 130 individual cliff edge failures from all time intervals were sampled on transects spaced $1 \mathrm{~m}$ alongshore, resulting in approximately 1300 non-zero transects. Transect retreats ranged from 0.01 to $10 \mathrm{~m}$, with a mean and median of $2.3 \mathrm{~m}$ and $2.0 \mathrm{~m}$, respectively. The maximum cumulative cliff retreat at single location during the study period was $10 \mathrm{~m}\left(1.8 \mathrm{~m} \mathrm{yr}^{-1}\right)$. Approximately $84 \%$ of the cliff edge experienced no detectable retreat over the study period based on the described methods.

The shapes of the retreat probability density functions for each time interval were similar, with a single peak ranging between 1 and $2.5 \mathrm{~m}$ (Fig. 9a), except for the bimodal Interval 5. The retreat events of combined large mean retreat intervals ( 1 and 2 ), small mean retreat intervals (3 through 7 ),

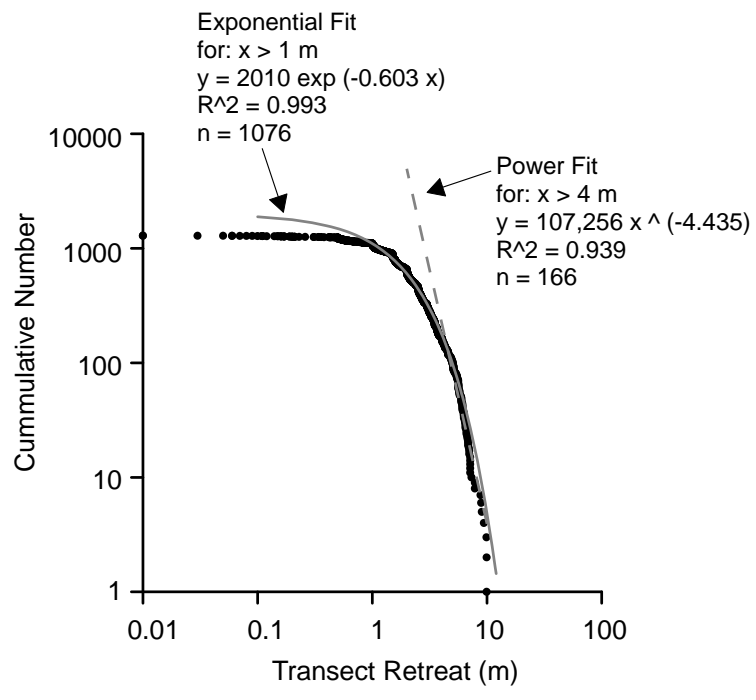

Fig. 10. Log of cumulative number of transect retreats versus log of transect retreat.

all-intervals, and cumulative retreat are all positive skewed with a peak around $2 \mathrm{~m}$ (Fig. 9b). However, the retreat distribution during large and small mean retreat intervals are significantly different (k-s test, $p=0.000031$, compare bold dashed with bold solid curve in Fig. 9b). During intervals of large mean section retreat, larger retreat events occur more often than expected compared to intervals with low mean section retreat. The converse is also true suggesting the distributions of cliff retreat may differ for time periods with varying amounts of overall failure activity.

The distributions of cumulative (e.g. total on transects) and average-all-interval retreat differ (Fig. 9b) because locations that retreat more than once are amalgamated into a single value in the cumulative distribution. The cumulative distribution of all individual retreat measurements (Fig. 10) fits better to an exponential distribution rather than a powerlaw, particularly for medium size events where the powerlaw fit deviates for values $>4 \mathrm{~m}$. A single failure affects multiple adjacent transect retreat measurements, and the nonindependence of transects probably contributed to power law deviation, along with amalgamation and under sampling of small areas.

\subsection{Mean interval cliff retreat}

The mean cliff retreat (averaged over the unprotected cliff section, including transects with no change) during each interval ranged from 2 to $16 \mathrm{~cm}$. The average retreat rate of $7.8 \mathrm{~cm} \mathrm{yr}^{-1}$ is consistent with rates measured from 1952 to 1994 of about $8 \mathrm{~cm} \mathrm{yr}^{-1}$ (Benumof and Griggs, 1999; Moore et al., 1999; Benumof et al., 2000). Maximum mean cliff retreat, number of failures, and the extent of alongshore change (Table 1) all occurred during Intervals 1 and 2. 


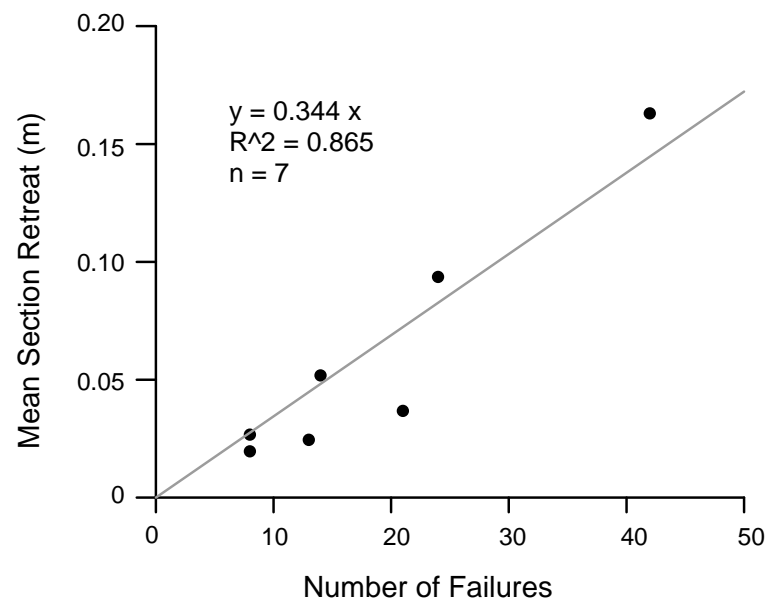

Fig. 11. Mean retreat (over the unprotected cliffs) versus the number of failures during each time interval.

If the size distribution of retreats were constant from interval to interval, then the mean retreat and number of failures in the interval would be linearly related, as was only approximately observed (Fig. 11). Mean retreat values in Intervals 1 and 2 were elevated above the best fit line because large slides occur disproportionally more often in the intervals with the most slides (Fig. 11).

\subsection{Spatial distribution of cliff retreat}

Retreat occurred along less than $3 \%$ of the cliff length in all intervals except Interval 2, when $7 \%$ of the section retreated. In total, about $1150 \mathrm{~m}$ of the unprotected cliffs experienced measurable cliff retreat during the study period. Forty eight of the failure footprints were spatially adjacent to at least one other failure resulting in 20 amalgamated footprints and $135 \mathrm{~m}$ of cliff retreating more than once.

The potential presence of short-term cliff retreat hot spots (Young et al., 2009a) was investigated with a simple Monte Carlo simulation of cliff retreat for the study period. The simulated cliff retreat for each time interval used the observed interval failure events and random spatial placement along the $7.1 \mathrm{~km}$ (unprotected) cliff section.

The random spatial placement of the Monte Carlo simulation over-predicted the maximum cumulative cliff retreat by $6 \mathrm{~m}$ (Fig. 12), and the observed alongshore extent of cliff retreat was about $50 \mathrm{~m}$ smaller than the Monte Carlo mean (Fig. 13). The differences between the Monte Carlo simulation and observations are consistant with cliff retreat history at a particular location influencing subsequent cliff retreat. For example, the simulated alongshore extent of failures can be made to match the observations by forcing some small to moderate failures to coincide with previous events, creating non-random, short-term hot spots. Small failure events could redistribute stress to nearby locations causing strain accumulation and concentrating future failures

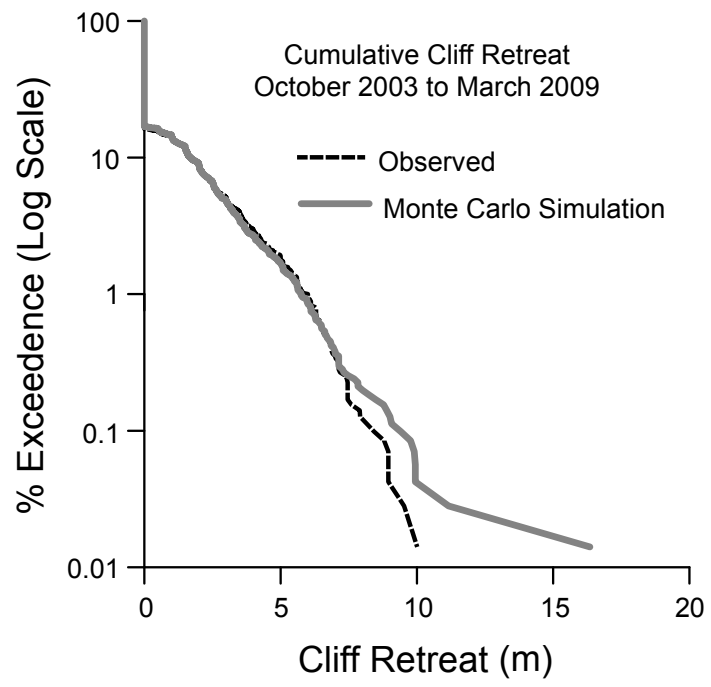

Fig. 12. Observed and Monte Carlo simulation (100 realizations) of $\%$ exceedence of cumulative transect cliff retreat. The most common cumulative retreat is zero. The observed and modeled cumulative retreat distributions differ for large, infrequent events, but the distributions are overall only marginally different (k-s test, $p=0.21$ ).

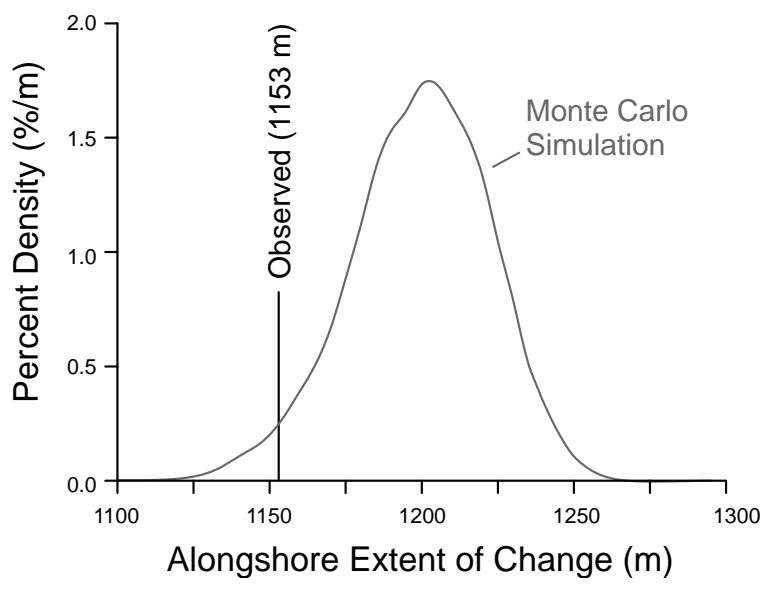

Fig. 13. Probability density function of alongshore extent of change based on a Monte Carlo simulation of random placement (solid curve). Only about $3 \%$ of the realizations had alongshore change extents less than or equal to the observed $1153 \mathrm{~m}$, suggesting observed failures tended to reoccur at some locations.

in both space and time. That is, the observed failures may be part of a progressive failure (Bjerrum, 1967; Bishop, 1971; Petley et al., 2005), or sequence of successive coastal failures (e.g. Hutchison, 1969; Brunsden and Jones, 1976; Alveirinho Dias and Neal, 1992; Collins and Sitar, 2008; Young et al., 2009a) where an intial failure may result in adjacent unstable rock masses (Chowdhury et al., 2010). Rosser et al. (2007) suggested that small failures preceded larger events at the same and nearby locations. Lim et al. (2010) emphasized that 
sequential failures are a "connected process", and stressed the importance of including non-random events in coastal cliff erosion models. The random simulation over-prediction of maximum cumulative retreat suggests that a large failure is relatively unlikely to be followed by more large failures at the same location over short time periods. All locations that retreated at least $6.9 \mathrm{~m}$ during one time interval did not retreat in any other interval. Longer data sets are required to test these preliminary suggestions.

\subsection{Temporal distribution of cliff retreat}

Relationships between erosional processes or failure triggering events (waves, rainfall, and seismicity) and cliff retreat could not be established statistically. Although the most cliff retreat and rainfall both were in Interval 2, the second largest amount of retreat occurred during time Interval 1, when rainfall was relatively light (Table 1, Fig. 4). The retreat in Interval 1 might have resulted from wave action, however Intervals 4, 6, and 7, had similar wave conditions with relatively little cliff retreat. Heavy rainfall in Interval 2 might have triggered failures that would have otherwise occurred from wave action in subsequent time intervals, resulting in abnormally large cliff retreat during Interval 2 and low retreat afterwards. Longer data sets are required to confirm the suggestion that, in these slowly retreating cliffs, nonrandom failure sequences serve to decouple failures from local environmental forcing. In the comparatively softer, more erosive cliffs in northern San Diego County, cliff erosion and rainfall in the study period were well correlated (Young et al., 2009b).

\section{Summary}

This cliff failure inventory provides the basic statistics of cliff edge retreat caused by medium and large size planimetric cliff changes along $7.1 \mathrm{~km}$ of unprotected rocky coastal cliffs over 5.5 years. Footprint areas of the 130 individual cliff edge failures ranged between 3 and $268 \mathrm{~m}^{2}$. On this short (5.5 yearr) time scale, "no change" was the most common observation ( $84 \%$ of the cliff edge). Probability distributions of non-zero cliff retreat during each time interval usually had a single peak between 1 and $2.5 \mathrm{~m}$. Intervals with high mean retreat had elevated numbers of failure in all class sizes, and also contained the largest individual retreats. Small and medium failures tended to reoccur preferentially (relative to randomly) near previous small and medium failures, forming short-term hot spots. Large failures were less likely than random to reoccur near previous large failures, but longer records are needed to confirm this statistically tentative result. Cumulative distributions of failure parameters (area, retreat, and length) follow an inverse power-law for medium to large size events and roll off for (poorly sampled) small events, similar to previously reported distributions of coastal and inland mass movements.
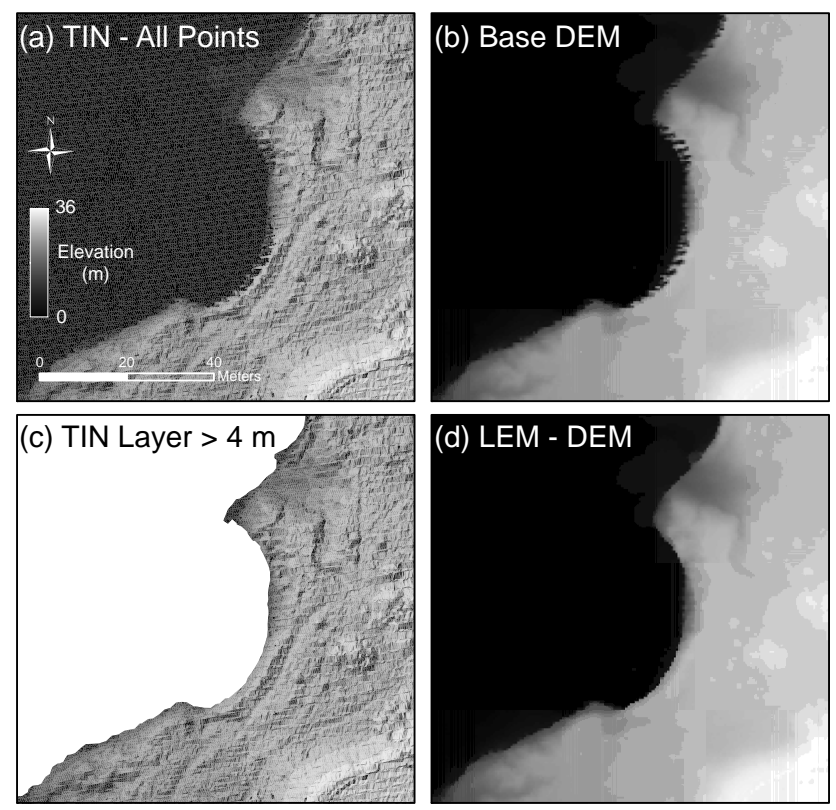

Fig. A1. Example of the "Layered Elevation Mosaic" - Digital Elevation Model (LEM-DEM) technique. (a) Initial TIN created from all points and the associated DEM (b), showing how points collected in seacaves and notches produce pits and a jagged, incorrect cliff edge. (c) A TIN layer produced from points greater than $4 \mathrm{~m}$ in elevation, showing the removal of seacave and notch points. (d) The final LEM-DEM which has eliminated the over vertical surfaces while maintaining the complex cliff topography and a well-defined cliff edge.

\section{Appendix A}

\section{LEM-DEM}

Simple interpolation of the lidar point data can produce pits and a faulty cliff edge (Fig. A1a and b). These problems were alleviated using an automated method termed here as a Layered Elevation Mosaic (LEM). The method consists of (1) sorting the point data by elevation into a series of layers, where each layer is assigned an increasing minimum elevation, (2) creation of triangulated irregular networks (TIN) for each layer, (3) conversion of each TIN to a DEM, and (4) creating a mosaic of all the DEM layers by maximum elevation. For this study, the elevation layers were incremented by $3 \mathrm{~m}$. For example, the elevation range for the layers were: minimum-maximum (layer 1, base layer, Fig. A1b), 1-m maximum (layer 2), 4-m maximum (layer 3, Fig. A1c), 7-m maximum (layer 4), and so on. After triangulating each point layer, facets with edges longer than $2 \mathrm{~m}$ were removed to maintain coverage only in areas with satisfactory point density. Next, each TIN layer was converted into a $0.5-\mathrm{m}$ resolution DEM with a "natural neighbors" interpolation. The boundaries of each DEM were assigned prior to the interpolation to ensure cell alignment 
between each DEM. Lastly, the final LEM-DEM (Fig. A1d) was produced by selecting the maximum grid cell elevation from all the DEM layers.

Table A1. Landslide attributes.

\begin{tabular}{|c|c|c|c|c|c|c|}
\hline $\begin{array}{l}\text { Time } \\
\text { Interval }\end{array}$ & $\left(\mathrm{m}^{2}\right)$ & $\begin{array}{r}\text { Along- } \\
\text { shore } \\
\text { Length } \\
(\mathrm{m})\end{array}$ & $\begin{array}{c}\text { Mean } \\
\text { Transect } \\
\text { Retreat } \\
\text { (m) }\end{array}$ & $\begin{array}{c}\text { Max } \\
\text { Transect } \\
\text { Retreat } \\
\text { (m) }\end{array}$ & $\begin{array}{c}\text { UTM } \\
\text { Northing }\end{array}$ & $\begin{array}{c}\text { UTM } \\
\text { Easting }\end{array}$ \\
\hline 1 & 80.75 & 17.00 & 4.81 & 6.26 & 3621773 & 475949 \\
\hline 1 & 8.25 & 6.00 & 1.39 & 2.46 & 3620899 & 475815 \\
\hline 1 & 18.5 & 8.00 & 2.42 & 3.94 & 3620832 & 475828 \\
\hline 1 & 18.5 & 11.00 & 1.73 & 2.74 & 3620120 & 475980 \\
\hline 1 & 20 & 11.00 & 1.83 & 2.68 & 3620109 & 475985 \\
\hline 1 & 15.25 & 8.00 & 1.99 & 3.02 & 3619375 & 475995 \\
\hline 1 & 17.25 & 8.00 & 2.19 & 3.36 & 3619198 & 476046 \\
\hline 1 & 10 & 6.00 & 1.86 & 2.78 & 3617575 & 476211 \\
\hline 1 & 11 & 7.00 & 1.57 & 2.50 & 3617430 & 476287 \\
\hline 1 & 11 & 8.00 & 1.38 & 1.50 & 3617421 & 476287 \\
\hline 1 & 26.25 & 11.00 & 2.41 & 4.00 & 3617112 & 476367 \\
\hline 1 & 15 & 7.00 & 2.17 & 3.57 & 3616717 & 476552 \\
\hline 1 & 205.5 & 44.00 & 4.75 & 9.94 & 3616625 & 476531 \\
\hline 1 & 26 & 12.00 & 2.26 & 3.41 & 3616150 & 476696 \\
\hline 1 & 8.75 & 7.00 & 1.31 & 2.02 & 3616081 & 476737 \\
\hline 1 & 29.5 & 14.00 & 2.04 & 3.54 & 3615501 & 476868 \\
\hline 1 & 19.5 & 8.00 & 2.32 & 3.73 & 3615281 & 476886 \\
\hline 1 & 35.75 & 10.00 & 3.75 & 5.22 & 3615203 & 476940 \\
\hline 1 & 7 & 6.00 & 1.17 & 1.71 & 3615153 & 476991 \\
\hline 1 & 16.75 & 11.00 & 1.48 & 2.11 & 3614866 & 477026 \\
\hline 1 & 6.5 & 4.00 & 1.49 & 2.55 & 3614425 & 477038 \\
\hline 1 & 10 & 4.00 & 2.41 & 3.73 & 3615279 & 476893 \\
\hline 1 & 22.75 & 13.00 & 1.75 & 3.03 & 3622296 & 476107 \\
\hline 1 & 15.25 & 7.00 & 2.31 & 3.35 & 3615148 & 476995 \\
\hline 2 & 15 & 7.00 & 2.21 & 3.53 & 3621382 & 475955 \\
\hline 2 & 34.5 & 16.00 & 2.12 & 3.07 & 3621219 & 476017 \\
\hline 2 & 4.25 & 3.00 & 1.37 & 1.54 & 3617366 & 476311 \\
\hline 2 & 6.25 & 6.00 & 1.08 & 2.32 & 3617346 & 476305 \\
\hline 2 & 3.75 & 3.00 & 1.15 & 1.77 & 3617194 & 476309 \\
\hline 2 & 11.75 & 8.00 & 1.72 & 2.34 & 3617193 & 476313 \\
\hline 2 & 32.25 & 11.00 & 2.92 & 4.40 & 3614656 & 477024 \\
\hline 2 & 3.25 & 4.00 & 0.75 & 1.19 & 3615991 & 476687 \\
\hline 2 & 14 & 8.00 & 1.76 & 2.37 & 3621903 & 476018 \\
\hline 2 & 6 & 7.00 & 0.76 & 1.15 & 3619217 & 476037 \\
\hline 2 & 13 & 8.00 & 1.56 & 2.25 & 3618706 & 476052 \\
\hline 2 & 23 & 12.00 & 1.88 & 2.53 & 3618347 & 476090 \\
\hline 2 & 19 & 11.00 & 1.78 & 3.02 & 3618328 & 476099 \\
\hline 2 & 22.25 & 14.00 & 1.60 & 3.61 & 3617505 & 476200 \\
\hline 2 & 16.75 & 11.00 & 1.69 & 4.08 & 3617097 & 476400 \\
\hline 2 & 39.75 & 21.00 & 1.90 & 3.66 & 3616842 & 476569 \\
\hline 2 & 7 & 4.00 & 1.61 & 2.34 & 3615232 & 476960 \\
\hline 2 & 9.5 & 7.00 & 1.25 & 1.88 & 3615227 & 476953 \\
\hline 2 & 8 & 6.00 & 1.26 & 2.96 & 3614659 & 477013 \\
\hline 2 & 17.75 & 13.00 & 1.41 & 2.30 & 3618233 & 476089 \\
\hline 2 & 19.75 & 11.00 & 1.82 & 2.75 & 3615492 & 476866 \\
\hline 2 & 12.25 & 9.00 & 1.50 & 2.59 & 3614579 & 477056 \\
\hline 2 & 6 & 4.00 & 1.71 & 2.56 & 3619631 & 475982 \\
\hline 2 & 268.25 & 68.00 & 3.93 & 7.13 & 3617464 & 476268 \\
\hline 2 & 44.5 & 21.00 & 2.16 & 4.73 & 3615213 & 477001 \\
\hline 2 & 9 & 6.00 & 1.77 & 3.50 & 3614801 & 477014 \\
\hline 2 & 20.75 & 9.00 & 2.59 & 3.76 & 3614587 & 477058 \\
\hline 2 & 11.75 & 6.00 & 2.01 & 3.67 & 3614500 & 477048 \\
\hline 2 & 13.5 & 9.00 & 1.63 & 3.03 & 3619646 & 475978 \\
\hline 2 & 7.25 & 6.00 & 1.17 & 1.50 & 3619223 & 476034 \\
\hline 2 & 155 & 27.00 & 5.76 & 7.14 & 3621898 & 476009 \\
\hline
\end{tabular}

\begin{tabular}{|c|c|c|c|c|c|c|}
\hline 2 & 97 & 24.00 & 4.08 & 7.00 & 3621479 & 475941 \\
\hline 2 & 9.5 & 8.00 & 1.13 & 2.00 & 3621404 & 475927 \\
\hline & 13 & 6.00 & 2.25 & 2.63 & 3620826 & 475838 \\
\hline & 10 & 6.00 & 1.59 & 2.41 & 3620653 & 475875 \\
\hline & 4.5 & 2.00 & 2.37 & 2.63 & 3619522 & 475989 \\
\hline & 21.5 & 12.00 & 1.86 & 3.61 & 3619336 & 476003 \\
\hline & 15 & 9.00 & 1.69 & 2.53 & 3619189 & 476052 \\
\hline & 28.75 & 13.00 & 2.14 & 3.41 & 3619180 & 476057 \\
\hline & 17.25 & 10.00 & 1.85 & 2.99 & 3619129 & 476068 \\
\hline & 9 & 10.00 & 0.83 & 1.51 & 3618989 & 476076 \\
\hline & 45.5 & 17.00 & 2.68 & 4.51 & 3618492 & 476061 \\
\hline 3 & 7.25 & 5.00 & 1.68 & 2.52 & 3618459 & 476046 \\
\hline 3 & 6.25 & 6.00 & 1.01 & 1.99 & 3618436 & 476063 \\
\hline 3 & 4.5 & 4.00 & 1.22 & 1.78 & 3618262 & 476098 \\
\hline 3 & 6.25 & 5.00 & 1.20 & 2.64 & 3618248 & 476090 \\
\hline 3 & 8.75 & 5.00 & 1.81 & 2.38 & 3617471 & 476229 \\
\hline 3 & 6.25 & 5.00 & 1.27 & 1.94 & 3617467 & 476265 \\
\hline 3 & 11 & 8.00 & 1.56 & 2.50 & 3617239 & 476295 \\
\hline 3 & 21.75 & 13.00 & 1.74 & 2.64 & 3617165 & 476328 \\
\hline 3 & 12 & 7.00 & 1.73 & 2.45 & 3617115 & 476366 \\
\hline 3 & 7.75 & 6.00 & 1.43 & 2.01 & 3617073 & 476405 \\
\hline 3 & 26.25 & 9.00 & 2.96 & 5.79 & 3616914 & 476517 \\
\hline 3 & 9.5 & 7.00 & 1.43 & 2.17 & 3616689 & 476549 \\
\hline 3 & 38.25 & 18.00 & 2.26 & 3.16 & 3616328 & 476599 \\
\hline 4 & 4.5 & 6.00 & 0.66 & 0.79 & 3616169 & 476678 \\
\hline 4 & 9 & 5.00 & 1.76 & 2.53 & 3616161 & 476688 \\
\hline 4 & 8 & 5.00 & 1.75 & 2.38 & 3616158 & 476693 \\
\hline 4 & 54 & 20.00 & 2.74 & 4.74 & 3616078 & 476739 \\
\hline 4 & 14.5 & 9.00 & 1.81 & 2.64 & 3615980 & 476733 \\
\hline 4 & 12.75 & 8.00 & 1.71 & 3.16 & 3615477 & 476856 \\
\hline 4 & 13.5 & 10.00 & 1.35 & 2.50 & 3615216 & 476987 \\
\hline 4 & 3.75 & 4.00 & 0.94 & 1.69 & 3615143 & 476998 \\
\hline 4 & 15 & 7.00 & 2.31 & 3.46 & 3614897 & 477011 \\
\hline 4 & 3.5 & 4.00 & 0.97 & 1.72 & 3614652 & 477025 \\
\hline 4 & 7.5 & 8.00 & 0.88 & 2.01 & 3614426 & 477042 \\
\hline 4 & 8.5 & 8.00 & 1.09 & 1.88 & 3622302 & 476107 \\
\hline 4 & 14.25 & 10.00 & 1.32 & 2.63 & 3622286 & 476112 \\
\hline 4 & 12 & 8.00 & 1.68 & 3.20 & 3616142 & 476700 \\
\hline 4 & 6.75 & 5.00 & 1.51 & 2.21 & 3615042 & 476995 \\
\hline 4 & 11.5 & 8.00 & 1.42 & 2.54 & 3617289 & 476308 \\
\hline 4 & 5.25 & 4.00 & 1.50 & 2.01 & 3615198 & 477013 \\
\hline 4 & 24.5 & 6.00 & 4.34 & 5.93 & 3621637 & 475947 \\
\hline 4 & 4 & 5.00 & 0.85 & 1.64 & 3621631 & 475943 \\
\hline 4 & 4.25 & 4.00 & 1.04 & 1.56 & 3621203 & 476024 \\
\hline 4 & 16.5 & 11.00 & 1.40 & 3.25 & 3619591 & 475978 \\
\hline 5 & 9.75 & 8.00 & 1.24 & 2.11 & 3618382 & 476072 \\
\hline 5 & 94.5 & 29.00 & 3.32 & 4.82 & 3616983 & 476486 \\
\hline 5 & 54.5 & 18.00 & 3.03 & 4.01 & 3616091 & 476734 \\
\hline 5 & 8.25 & 6.00 & 1.27 & 1.89 & 3615208 & 476977 \\
\hline 5 & 5 & 5.00 & 1.50 & 3.00 & 3615044 & 476995 \\
\hline 5 & 7.25 & 4.00 & 1.50 & 2.00 & 3614885 & 477010 \\
\hline 5 & 3.75 & 5.00 & 0.81 & 1.45 & 3614422 & 477043 \\
\hline 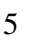 & 3.25 & 3.00 & 1.08 & 1.52 & 3614604 & 477056 \\
\hline 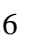 & 31.25 & 15.00 & 2.04 & 4.31 & 3619220 & 476033 \\
\hline 6 & 46.5 & 17.00 & 2.83 & 5.38 & 3621899 & 476006 \\
\hline 6 & 17.25 & 9.00 & 2.00 & 3.00 & 3620624 & 475899 \\
\hline 6 & 8.5 & 6.00 & 1.53 & 2.72 & 3620215 & 475932 \\
\hline 6 & 125.25 & 38.00 & 3.25 & 5.99 & 3619771 & 476019 \\
\hline 6 & 13.25 & 7.00 & 1.88 & 2.61 & 3619188 & 476055 \\
\hline 6 & 6.25 & 6.00 & 0.98 & 1.77 & 3618732 & 476053 \\
\hline
\end{tabular}




\begin{tabular}{rcrrrrr}
6 & 11.25 & 6.00 & 1.92 & 2.00 & 3618307 & 476106 \\
6 & 25.25 & 14.00 & 1.82 & 2.57 & 3618255 & 476092 \\
6 & 25 & 9.00 & 2.71 & 4.05 & 3617805 & 476159 \\
6 & 10.5 & 7.00 & 1.50 & 2.12 & 3617556 & 476216 \\
6 & 13 & 7.00 & 1.77 & 2.53 & 3617300 & 476307 \\
6 & 30.25 & 11.00 & 2.90 & 5.43 & 3616411 & 476588 \\
6 & 3 & 3.00 & 1.17 & 1.50 & 3616387 & 476600 \\
7 & 28 & 16.00 & 1.70 & 2.52 & 3616061 & 476739 \\
7 & 6.75 & 5.00 & 1.34 & 2.70 & 3616058 & 476733 \\
7 & 42.75 & 18.00 & 2.56 & 3.65 & 3614797 & 477010 \\
7 & 26 & 14.00 & 1.93 & 3.39 & 3614659 & 477017 \\
7 & 10.25 & 8.00 & 1.19 & 1.50 & 3614436 & 477038 \\
7 & 8.75 & 8.00 & 1.06 & 1.50 & 3614393 & 477056 \\
7 & 10.25 & 8.00 & 1.31 & 2.25 & 3621763 & 475952 \\
7 & 4 & 4.00 & 0.97 & 1.34 & 3615484 & 476865 \\
\hline
\end{tabular}

Acknowledgements. Lidar surveys were sponsored by the U.S. Army Corps of Engineers as part of the Southern California Beach Processes Study. Wave data collection was sponsored by the California Department of Boating and Waterways, and the U.S. Army Corps of Engineers, as part of the Coastal Data Information Program (CDIP). APY received Post-Doctoral Scholar support from the California Department of Boating and Waterways Oceanography Program. Portions of this work were conducted in collaboration with SPAWAR Systems Center Pacific under grant \#SI-1703 from the Strategic Environmental Research and Development Program (SERDP).

Here we also thank F. Marques and R. Calvo for reviews that significantly improved the manuscript.

Edited by: O. Katz

Reviewed by: F. Marques and R. Calvo

\section{References}

Alveirinho Dias, J. M. and Neal, W. J.: Sea cliff retreat in southern Portugal: profiles, processes and problems, J. Coastal Res., 8, 641-654, 1992.

Benumof, B. T. and Griggs, G. B.: The dependence of seacliff erosion rates, cliff material properties, and physical processes: San Diego County, California, Shore \& Beach, 67(4), 29-41, 1999.

Benumof, B. T., Storlazzi, C. D., Seymour, R. J., and Griggs, G. B.: The relationship between incident wave energy and seacliff erosion rates: San Diego County, California, J. Coastal Res., 16(4), 1162-1178, 2000.

Bishop, A. W.: The infuence of progressive failure on the method of stability analysis, Geotechnique, 21, 168-172, 1971.

Bjerrum, L.: Progressive failure of slopes of over consolidated plastic clay and clay shales, in: Proceedings American Society Civil Engineers, Soc. Civ. Eng., Journal of Soil Mechanics and Foundations Division, 93, 1-49, 1967.

Brardinoni, F. and Church, M.: Representing the landslide magnitude-frequency relation: Capilano River basin, British Columbia, Earth Surf. Proc. Land., 29(1), 115-124, 2004.

Brunetti, M. T., Guzzetti, F., and Rossi, M.: Probability distributions of landslide volumes, Nonlin. Processes Geophys., 16, 179-188, doi:10.5194/npg-16-179-2009, 2009.
Brunsden, D. and Jones, D. K. C.: The evolution of landslide slopes in Dorset, Philos. T. R. Soc. A, 283, 605-631, 1976.

Budetta, P.: Stability of an undercut sea-cliff along a Cilento coastal stretch (Campania, Southern Italy), Nat. Hazards, in press, doi:10.1007/s11069-010-9565-y, 2010.

Cambers, G.: Temporal scales in coastal erosion systems, T. I. Brit. Geogr., 1(2), 246-256, 1976.

Chowdhury, R., Flentje, P., and Bhattacharya, G.: Geotechnical Slope Analysis, CRC Press/Balkema, Leiden, The Netherlands, 737 pp., 2010.

Collins, B. D. and Sitar, N.: Processes of coastal bluff erosion in weakly lithified sands, Pacifica, California, USA, Geomorphology, 97, 483-501, 2008.

Dai, F. C. and Lee, C. F.: Frequency-volume relation and prediction of rainfall-induced landslides, Eng. Geol., 59, 253-266, 2001.

Dong, P. and Guzzetti, F.: Frequency-size statistics of coastal softcliff erosion, J. Waterw. Port C.-ASCE, 131(1), 37-42, 2005.

Dussauge-Peisser, C., Helmstetter, A., Grasso, J.-R., Hantz, D., Desvarreux, P., Jeannin, M., and Giraud, A.: Probabilistic approach to rock fall hazard assessment: potential of historical data analysis, Nat. Hazards Earth Syst. Sci., 2, 15-26, doi:10.5194/nhess-2-15-2002, 2002.

Emery, K. O. and Kuhn, G. G.: Sea cliffs: their processes, profiles, and classification, Geol. Soc. Am. Bull., 93, 644-654, 1982.

Federal Geographic Data Committee: Geospatial positioning accuracy standards, FGDC-STD-007.3-1998, 28 pp., 1998.

Flick, R. E.: Shoreline Erosion Assessment and Atlas of the San Diego Region, 2 volumes, Sacramento, California: California Department of Boating and Waterways, 1994.

Flick, R. E.: Dana Point to the international border, in: Living with the Changing California Coast, edited by: Griggs, G., Patsch, K., and Savoy, L., University of California Press, Berkeley and Los Angeles, California, 474-514, 2005.

Furlan, C.: Hierarchical random effect models for coastal erosion of cliffs in the Holderness coast, Stat. Method. Appl., 17, 335-350, 2008.

Guzzetti, F., Malamud, B. D., Turcotte, D. L., and Reichenbach, P.: Power-law correlations of landslide areas in central Italy, Earth Planet. Sc. Lett., 195, 169-183, 2002.

Hall, J. W., Meadowcroft, I. C., Lee, E. M., and Van Gelder, P. H. A. J. M.: Stochastic simulation of episodic soft cliff recession, Coast. Eng., 46, 159-174, 2002.

Hampton, M. A.: Gravitational failure of sea cliffs in weakly lithified sediment, Environ. Eng. Geosci., 8(3), 175-191, 2002.

Hapke, C. J. and Reid, D.: socal_transects.shp - Cliff Erosion Rates for Southern California Generated at a $20 \mathrm{~m}$ Transect Spacing, 1928-1998: Open-File Report 2007-1112, Coastal and Marine Geology Program, U.S. Geological Survey, Pacific Science Center, Santa Cruz, California, 2007a.

Hapke, C. J. and Reid, D.: National Assessment of Shoreline Change, Part 4: Historical Coastal Cliff Retreat along the California Coast: U.S. Geological Survey Open-file Report 2007-1133, 2007b.

Hergarten, S.: Landslides, sandpiles, and self-organized criticality, Nat. Hazards Earth Syst. Sci., 3, 505-514, doi:10.5194/nhess-3505-2003, 2003.

Hovius, N., Stark, C. P., and Allen, P. A.: Sediment flux from a mountain belt derived by landslide mapping, Geology, 25, 231234, 1997. 
Hutchinson, J. N.: A reconsideration of the coastal landslides at Folkestone Warren, Kent, Geotechnique, 19, 6-38, 1969.

Kennedy, M. P.: Sea-cliff erosion at Sunset Cliffs, San Diego, California Geology, 27-31, February 1973.

Kennedy, M. P.: Geology of the San Diego metropolitan area, western area, California Division of Mines and Geology Bulletin, 200, 56 pp., 1975.

Kogure, T., Aoki, H., Maekado, A., Hirose, T., and Matsukura, Y.: Effect of the development of notches and tension cracks on instability of limestone coastal cliffs in the Ryukyus, Japan, Geomorphology, 80(3-4), 236-244, 2006.

Kogure, T. and Matsukura, Y.: Critical notch depths for failures of coastal limestone cliffs: case study at Kuro-shima Island, Okinawa, Japan, available at: http://dx.doi.org/10.1002/esp. 1940, Earth Surf. Proc. Land., 35(9), 1044-1056, 2010.

Kuhn, G. G. and Shepard, F. P.: Sea Cliffs, Beaches, and Coastal Valleys of San Diego County: Some Amazing Histories and Some Horrifying Implications, Berkeley, California, University of California Press, 193 pp., 1984.

Lee, E. M., Hall, J. W., and Meadowcroft, I. C.: Coastal cliff recession: the use of probabilistic prediction methods, Geomorphology, 40, 253-269, 2001.

Lee, E. M., Meadowcroft, I. C., Hall, J. W., and Walkden, M.: Coastal landslide activity: a probabilistic simulation model, B. Eng. Geol. Environ., 61, 347-355, 2002.

Lim, M., Rosser, N. J., Allison, R. J., and Petley, D. N.: Erosional processes in the hard rock coastal cliffs at Staithes, North Yorkshire, Geomorphology, 114, 12-21, 2010.

Malamud, B. D., Turcotte, D. L., Guzzetti, F., and Reichenbach P.: Landslide inventories and their statistical properties, Earth Surf. Proc. Land., 29, 687-711, 2004.

Marques, F. M. S. F.: Magnitude-frequency of sea cliff instabilities, Nat. Hazards Earth Syst. Sci., 8, 1161-1171, doi:10.5194/nhess8-1161-2008, 2008.

Milheiro-Oliveira, P.: Bayesian statistical methods for modeling and prediction of major landslides in coastal cliffs, Coast. Eng. J., 49(1), 45-61, 2007.

Moore, L. J. and Griggs, G. B.: Long-term cliff retreat and erosion hotspots along the central shores of the Monterey Bay National Marine Sanctuary, Mar. Geol., 181, 265-283, 2002.

Moore, L. J., Benumof, B. T., and Griggs, G. B.: Coastal erosion hazards in Santa Cruz and San Diego Counties, California, in: Crowell, M. and Leatherman, S. P., Coastal Erosion Mapping and Management, J. Coastal Res., SI 28, 121-139, 1999.

O'Reilly, W. C. and Guza, R. T: Comparison of spectral refraction and refraction-diffraction wave models, J. Waterw. Port C.ASCE, 117, 199-215, 1991.

O'Reilly, W. C. and Guza, R. T.: Assimilating Coastal Wave Observations in Regional Swell Predictions, Part I: Inverse Methods, J. Phys. Oceanogr., 28, 679-691, 1998.

Pelletier, J. D., Malamud, B. D., Blodgett, T., and Turcotte, D. L.: Scale-invariance of soil moisture variability and its implications for the frequency-size distribution of landslides, Eng. Geol., 48, 255-268, 1997.
Petley, D. N., Higuchi, T., Petley, D. J., Bulmer, M. H., and Carey, J.: The development of progressive landslide failure in cohesive materials, Geology, 33(3), 201-204, 2005.

Quinn, J. D., Phillip, L. K., and Murphy, W.: Understanding the recession of the Holderness Coast, east Yorkshire, UK: a new presentation of temporal and spatial patterns, Q. J. Eng. Geol. Hydroge., 42, 165-178, 2009.

Rosser, N., Lim, M., Petley, D., Dunning, S., and Allison, R.: Patterns of precursory rockfall prior to slope failure, J. Geophys. Res., 112, F04014, doi:10.1029/2006JF000642, 2007.

Shepard, F. P. and Grant IV, U. S.: Wave erosion along the southern California coast, Bull. Geol. Soc. Am., 58, 919-926, 1947.

Shepard, F. P. and Wanless, H. R.: Our Changing Coastlines, McGraw-Hill Inc. New York, New York, 579 pp., 1971.

Spaulding, G. A. and Crampton, W. F.: Pump station 35: assessing coastal bluff stability - a geomorphic perspective, in: Coastal Processes and Engineering Geology of San Diego, California, edited by: Stroh, R. C., San Diego Association of Geologists, 75-91, 2001.

Stark, C. P. and Hovius, N.: The characterization of landslide size distributions, Geophys. Res. Lett., 28(6), 1091-1094, 2001.

Sunamura, T.: Geomorphology of Rocky Coasts, John Wiley, Hoboken, N. J., 302 pp., 1992.

Teixeira, S. B.: Slope mass movements on rocky sea-cliffs: a powerlaw distributed natural hazard on the Barlavento Coast, Algarve, Portugal, Cont. Shelf Res., 26, 1077-1091, 2006.

ten Brink, U. S., Barkan, R., Andews, B. D., and Chaytor, J. D.: Size distributions and failure initiation of submarine and subaerial landslides, Earth Planet. Sc. Lett., 287, 31-42, 2009.

Trenhaile, A. S.: The Geomorphology of Rock Coasts, Oxford Univeristy Press, Oxford, UK, 384 pp., 1987.

Varnes, D. J.: Slope movement types and processes, in: Landslides, analysis and control, edited by: Schuster, R. L. and Krizek, R. J., National Academy of Sciences Transportation Research Board, Sp. Rep. No. 176, 11-33, 1978.

Wehr, A. and Lohr, U.: Airborne laser scanning - an introduction and overview, ISPRS J. Photogramm., 54(2-3), 68-82, 1999.

Williams, B. M., Lu, C. C., and Qin, W.: Coastal bluff erosion numerical model using Monte Carlo simulation technique and Sunamura's equation, Shore \& Beach, 72(3), 3-9, 2004.

Young, A. P. and Ashford, S. A.: Instability investigation of cantilevered seacliffs, Earth Surf. Proc. Land., 33, 1661-1677, 2008.

Young, A. P., Flick, R. E., Gutierrez, R., and Guza, R. T.: Comparison of short-term seacliff retreat measurement methods in Del Mar, California, Geomorphology, 112, 318-323, 2009a.

Young, A. P., Guza, R. T., Flick, R. E., O'Reilly, W. C., and Gutierrez, R.: Rain, waves, and the short-term evolution of composite seacliffs in southern California, Mar. Geol., 267, 17, 2009b. 